\title{
Brain Ways: Meynert, Bachelard and the Material Imagination of the Inner Life
}

\author{
SCOTT PHELPS * \\ Department of Psychiatry, Division of Social and Transcultural Psychiatry, \\ McGill University, 1033 Pine Ave, Montreal, Quebec H3A 1A2, Canada
}

\begin{abstract}
The Austrian psychiatrist Theodor Meynert's anatomical theories of the brain and nerves are laden with metaphorical imagery, ranging from the colonies of empire to the tentacles of jellyfish. This paper analyses among Meynert's earliest works a different set of less obvious metaphors, namely, the fibres, threads, branches and paths used to elaborate the brain's interior. I argue that these metaphors of material, or what the philosopher Gaston Bachelard called 'material images', helped Meynert not only to imaginatively extend the tracts of fibrous tissue inside the brain but to insinuate their function as pathways co-extensive with the mind. Above all, with reference to Bachelard's study of the material imagination, I argue that Meynert helped entrench the historical intuition that the mind, whatever it was, consisted of some interiority - one which came to be increasingly articulated through the fibrous confines of the brain.
\end{abstract}

Keywords: Theodor Meynert, Gaston Bachelard, Material images, Brain anatomy, Psychiatry, Interiority

'The nervous system in its activity is no longer such a mystery to us as it once was', boasted the German philosopher Friedrich Albert Lange in 1877. ${ }^{1}$ This was in large part, according to Lange, thanks to the 'latest brain research' of the Austrian psychiatrist and anatomist Theodor Meynert. ${ }^{2}$ In barely over a decade after joining the medical faculty at the University of Vienna, Meynert had been able to demonstrate, as far as Lange

* Email address for correspondence: phelps.scott@gmail.com

I would like to thank the guest editors, Katja Guenther and Volker Hess, for the opportunity to contribute to this special issue and for their sustained critical attention and encouragement throughout the revisions process. I would also like to thank the anonymous reviewers for their incisive and invaluable comments. For their helpful suggestions to earlier versions of this paper, I am grateful to the participants of the Joint Atlantic Seminar for the History of Biology at Johns Hopkins University in April 2014 and of the special workshop, 'Neurosciences et psychiatrie: Approches historiques et philosophiques', organised by Claude Debru and Mireille Delbraccio at the École Normale Supérieure in June 2014. Finally, I would like to acknowledge Philipp Lehmann, Laurence Kirmayer, Beau Bellenfant and Richard Sha for the stimulating conversations which provided me with a crucial sounding board at the early stages of writing.

${ }^{1}$ Friedrich Albert Lange, Geschichte des Materialismus und Kritik seiner Bedeutung in der Gegenwart, Vol. 2: Geschichte des Materialismus seit Kant, 3rd edn, 2 vols (Iserlohn: Baedeker, 1876), I2: 312.

${ }^{2}$ Ibid., 2: 356-9. 
was concerned, that consciousness was no more than 'a function of the cortex', the self was 'nothing but the fusion of the sense-perceptions', and the soul was ultimately a 'fiction'. 3

That Meynert's research on the brain and nerves had an impact not just on medicine but also on the philosophy of the mind and the 'history of materialism' is readily apparent from Lange's enthusiastic statements. ${ }^{4}$ What this paper seeks to answer is why. What about Meynert's work made it cogent and compelling? What about it seemed capable of dispelling the mystery of the nervous system and dispensing with the unique inwardness of the mind $?^{5}$ Part of the answer, I argue, lies with Meynert's images of the brain's material and the collocation of its fleshy, fibrous inner stuff with the interiority of the mind.

If, as the title of this Special Issue suggests, there are things capable of catching the soul, then one of the first places to look would seem to be inside the brain. This is not at all obvious; at least, it was not always. ${ }^{6}$ But one of the reasons it would seem so now

${ }^{3}$ Ibid., 2: 357-8, 371, 417.

${ }^{4}$ Along with Lange, Meynert's ideas about the brain and nerves stimulated other philosophers and psychologists (although this distinction was by no means hard and fast), such as William James and Wilhelm Wundt and to varying degrees, the physicist Ernst Mach, as well as the founder of phenomenology, Franz Brentano. Otto Marx discusses some of the philosophical aspects of Meynert's theories, especially his appropriation of Rudolf Hermann Lotze and to a lesser extent Johann Friedrich Herbart: Otto M. Marx, 'Nineteenth-Century Medical Psychology: Theoretical Problems in the Work of Griesinger, Meynert and Wernicke', Isis, 61, 3 (1970), 361-4. Lesky and Albertazzi offer the brief but tantalising suggestion that Brentano and Meynert were friends through the University of Vienna's Philosophische Gesellschaft: Erna Lesky, The Vienna Medical School of the 19th Century (Baltimore, MD: Johns Hopkins University Press, 1976), 339; Liliana Albertazzi, Immanent Realism: An Introduction to Brentano (Dordrecht: Springer, 2006), 40. Katja Guenther addresses William James' mischaracterisation of some of Meynert's metaphors: Katja Guenther, 'A Body Made of Nerves: Reflexes, Body Maps and the Limits of the Self in Modern German Medicine' (PhD thesis, Harvard University, 2009), ch. 1, passim. For discussion of the mid-nineteenth-century 'materialism debate', alternately called the 'struggle over the soul', see Frederick Gregory, Scientific Materialism in Nineteenth-Century Germany (Dordrecht: D. Reidel, 1977); Thomas E. Willey, Back to Kant: The Revival of Kantianism in German Social and Historical Thought, 1860-1914 (Detroit, MI: Wayne State University Press, 1978); Michael Hagner, 'Hirnforschung und Materialismus', in Kurt Bayertz et al. (eds), Weltanschauung, Philosophie und Naturwissenschaft im 19. Jahrhundert, Vol. 1: Materialismus-Streit, 3 vols (Hamburg: Meiner, 2007), 204-22; Gabriel Finkelstein, 'Emil Du Bois-Reymond on "The Seat of the Soul", , Journal of the History of the Neurosciences, 23, 1 (2014), 45-55; and Angus Nicholls and Martin Liebscher (eds), Thinking the Unconscious: Nineteenth-Century German Thought (Cambridge: Cambridge University Press, 2010).

5 This phrase comes from the title of novelist and essayist Marilynne Robinson's Terry lectures. Marilynne Robinson, Absence of Mind: The Dispelling of Inwardness from the Modern Myth of the Self (New Haven, CT: Yale University Press, 2010).

6 There is a vast and ever-growing scholarship on the development of the beliefs surrounding the imagery of the brain's solid tissue as container and captor of the soul. Georges Canguilhem, La Formation du concept de réflexe aux XVIIe et XVIIIe siècles, Bibliothèque de philosophie contemporaine, 1st edn, (Paris: Presses universitaires de France, 1955); Robert M. Young, Mind, Brain, and Adaptation in the Nineteenth Century: Cerebral Localization and Its Biological Context from Gall to Ferrier (Oxford: Clarendon Press, 1970); George S. Rousseau, 'Nerves, spirits and fibres: toward the origins of sensibility (1975)', in Nervous Acts: Essays on Literature and Sensibility (Palgrave Macmillan, 2005), 157-84; Charles Taylor, Sources of the Self: The Making of the Modern Identity (Cambridge, MA: Harvard University Press, 1989); Robert G. Frank, 'Thomas Willis and His Circle: Brain and Mind in Seventeenth-Century Medicine', in G.S. Rousseau (ed.),The Languages of Psyche: Mind and Body in Enlightenment Thought, (Berkeley, CA: University of California Press, 1991), 107-46; Marcel Gauchet, L'Inconscient cérébral, La Librairie du XXe siècle (Paris: Seuil, 1992); Mathias Kiefer, Die Entwicklung des Seelenbegriffs in der deutschen Psychiatrie ab der zweiten Hälfte des 19. Jahrhunderts unter dem Einfluss zeitgenössischer Philosophie (Essen: Blaue Eule, 1996); Shigehisa Kuriyama, The Expressiveness of the Body and the Divergence of Greek and Chinese Medicine (New York: Zone Books, 1999); Roy Porter, Flesh in the Age of Reason (London: Allen Lane, 2003); Robert L. Martensen, The Brain Takes Shape: An Early History (Oxford: Oxford University Press, 2004); Fernando Vidal and Saskia Brown, The Sciences of the Soul: The Early Modern Origins of Psychology (Chicago, IL: University of Chicago Press, 2011); Nima Bassiri, 'The Brain and the Unconscious Soul in Eighteenth-Century 
is in no small part thanks to the imaginative work of Theodor Meynert in the latter third of the nineteenth century. Even though many already maintained that if there was a soul it had to be seated inside the brain, Meynert made it all the more evident and all the more inevitable that not only was the soul embedded in the fleshy pulp of brain matter but also inextricably stuck there. By delineating various 'fibre-systems' in the brain and nerves, then deducing their different functions on the basis of their winding 'pathways' [Bahnen], Meynert elaborated new shapes and textures inside the brain and by doing so, he elaborated, indeed insinuated, the fleshed-out functions of the mind. ${ }^{7}$ Following the 'tracks' of fibre running through the tissues of the brain, he extrapolated their function as such, that is, material conduits holding the brain together and keeping its various parts intact. But even as he imagined these fibres as pathways or tracks inside the brain, he co-extended them and co-located them as pathways somehow equally inside the mind.

I argue that Meynert's initial success with his models of brain anatomy and nerve physiology had to do with a combination of his techniques of dissection and his tactics of description. By scraping away and pulling apart rather than strictly slicing or cutting across the cerebral material, he was able to visualise its fibrous composition and unravel its tracts of tissue as if tracing out different paths. Likewise, he reinforced this image of its winding interior by describing the tissue in terms of strings, threads, bands and cords. Even though neither these terms nor the techniques were original to Meynert alone, he combined them in new ways to deepen the sense of the material interior of the brain, and with it, to substantiate the image of the interiority of the mind.

To help make this point, I draw on the later works of the philosopher Gaston Bachelard, particularly what he called the 'material imagination' ${ }^{8}$ I propose, however, that Bachelard's distinction between science and the imagination can be seen to founder somewhat on the case of Meynert who, despite his reliance on images of the material, managed to build up on this very basis the scientific object of the mind and contribute thereby to the 'objective-making' of psychiatric knowledge. ${ }^{9}$ Put differently, although

Nervous Physiology: Robert Whytt's Sensorium Commune', Journal of the History of Ideas, 74, 3 (2013), 425-48.

${ }^{7}$ My use of 'elaboration' is in keeping with the basic argument of Robert Martensen in his discussion of Willis and Descartes, namely, that by Willis' elaboration of the nerve fibres deep within the brain, he exacted both textual and tissual delineations of the soul's form and function. Martensen, op. cit. (note 6), 49-55, 62-6. For more on the nuances of discursive elaboration and material articulation, see Kuriyama, op. cit. (note 6).

${ }^{8}$ Gaston Bachelard, L'Eau et les rêves: Essai sur l'imagination de la matièreBachelard, L'Air et les songes (Paris: Corti, 1943); Gaston Bachelard, La Terre et les rêveries de la volonté (Paris: Corti, 1948); Gaston Bachelard, La terre et les rêveries du repos: Essai sur les images de l'intimité (1948; repr., Paris: Corti, 1997); C.G. Christofides, 'Gaston Bachelard and the Imagination of Matter', Revue Internationale de Philosophie, 17, 66 (4) (January 1, 1963), 477-91; Dominique Lecourt, Bachelard, ou, Le Jour et la Nuit: Un essai du materialisme dialectique (Paris: Grasset, 1974); Mary Tiles, Bachelard, Science and Objectivity, Modern European Philosophy (Cambridge: Cambridge University Press, 1984); Mary McAllester Jones and Gaston Bachelard, Gaston Bachelard, Subversive Humanist: Texts and Readings, Science and Literature (Madison, WI: University of Wisconsin Press, 1991); Cristina Chimisso, Gaston Bachelard: Critic of Science and the Imagination (London; New York: Routledge, 2001).

${ }^{9}$ For more on the process of making science objective and the opposition between scientific knowledge and the poetic imagination, see Gaston Bachelard, The Formation of the Scientific Mind: A Contribution to a Psychoanalysis of Objective Knowledge, trans. Mary McAllester Jones (Manchester: Clinamen Press, 2002); Gaston Bachelard, The Psychoanalysis of Fire (1964; repr., Boston, MD: Beacon Press, 1987). For a revised history of objectivity and its emergence from the shadows of the 'epistemological malady' of subjectivity, see Lorraine Daston and Peter Galison, 'The Image of Objectivity', Representations, 40 (October 1, 1992), 81-128; Lorraine Daston and Peter Galison, Objectivity (New York: Zone Books, 2007). For the specific historical rendering of the mind as one such object of science, see Otniel Dror, 'Is the mind a scientific object of study? Lessons from history', in Christina E. Erneling and David Martel Johnson (eds), The Mind as a 
Bachelard's notion of the material imagination may help account for the historical persuasiveness of Meynert's research, it fails - albeit in a revealing manner - to address the historical fact that Meynert's work succeeded both as an expression of the material imagination and the activity of an anatomical science.

\section{Meynert, Anatomist and Psychiatrist}

Theodor Meynert became one of the first leaders of psychiatry as a clinical academic discipline on the basis of dissecting dead human brains. To some, this may seem puzzling. Why would a psychiatrist bother with dissection? In fact, Meynert was not trained as a psychiatrist since there was little of such available in the medical curriculum of the $1850 \mathrm{~s}^{10}$ Instead, he studied principally the teachings and techniques of pathological anatomy, practising how to cut open dead bodies and inspect the different tissues for signs of disease from one of the most skilled physicians of the discipline, Carl von Rokitansky. Indeed, Rokitansky along with Rudolf Virchow helped introduce pathological anatomy as a discipline to the medical curriculum. ${ }^{11}$ Still, this does not directly answer why Meynert's skill in dissecting post-mortem human tissue would help him later to lead psychiatry at the university level. That requires a brief digression on the state of the field around the time Meynert earned his medical degree in 1861.

That year the physician Wilhelm Griesinger published a new and expanded edition of his textbook on psychiatry, in which he emphatically argued for the need to study the symptoms and causes of mental illness strictly on the basis of brain diseases. ${ }^{12}$ Reacting against a certain strain of physicians, or 'alienists', who often managed patients in relatively large asylums, Griesinger called for a set of sweeping reforms that would incorporate many asylums and asylum-managers into nearby university-clinics and medical faculties so as to foster research on the somatic, neuropathological aspects of mental illness rather than to let the patients allegedly languish under the so-called

Scientific Object: Between Brain and Culture (New York: Oxford University Press, 2005), 101-17; Nikolas S. Rose and Joelle M. Abi-Rached, Neuro: The New Brain Sciences and the Management of the Mind (Princeton, NJ: Princeton University Press, 2013), 30.

${ }^{10}$ One of the exceptions was Ernst, Baron von Feuchtersleben who taught a version of psychiatry, or 'care of the soul' [Seelenheilkunde], at the University of Vienna starting in 1844. Lesky, op. cit. (note 4), 153-7; William M. Johnston, The Austrian Mind: An Intellectual and Social History, 1848-1938 (Berkeley, CA: University of California Press, 1972), 226. On the status of psychiatry in the early to middle nineteenth century, see Ulrike Hoffman-Richter, 'Die Wiener akademische Psychiatrie und die Geburt der Psychoanalyse', in Brigitta Keintzel and Eberhard Gabriel (eds), Gründe der Seele: Die Wiener Psychiatrie im 20. Jahrhundert (Vienna: Picus, 1999), 57-8; Michael Hagner, Homo cerebralis: Der Wandel vom Seelenorgan zum Gehirn (Berlin: Berlin Verlag, 1997); Erwin H. Ackerknecht, Kurze Geschichte der Psychiatrie (Stuttgart: Enke, 1957); Erwin H. Ackerknecht, 'Gudden, Huguenin, Hitzig: Hirnpsychiatrie im Burghölzli, 1869-79', Gesnerus, 35, 1-2 (1978), 66-78; Eric J. Engstrom, Clinical Psychiatry in Imperial Germany: A History of Psychiatric Practice (Ithaca, NY: Cornell University Press, 2003).

${ }^{11}$ Lesky, op. cit. (note 4), 107-8.

12 Wilhelm Griesinger, Die Pathologie und Therapie der psychischen Krankheiten: Für Aerzte und Studirende, 2nd edn (Stuttgart: Krabbe, 1861), 9-10; H.H. Eulner, Die Entwicklung der medizinischen Spezialfächer an den Universitäten des deutschen Sprachgebietes, Vol. 4 (Stuttgart: Enke, 1970), 260; Marx, op. cit. (note 4), 358-9; Bettina Wahrig-Schmidt, Der junge Wilhelm Griesinger im Spannungsfeld zwischen Philosophie und Physiologie: Anmerkungen zu den philosophischen Wurzeln seiner frühen Psychiatrie (Tübingen: Narr, 1985); Engstrom, op. cit. (note 10), 66-9; Eric J. Engstrom, 'Neurowissenschaften und Hirnforschung', in Heinz-Elmar Tenorth (ed.), Geschichte der Universität zu Berlin 1810-2010: Praxis ihrer Disziplinen, Transformation der Wissensordnung, Vol. 5 (Berlin: Akademie Verlag, 2010), 780; Heinz Schott and Rainer Tölle, Geschichte der Psychiatrie: Krankheitslehren, Irrwege, Behandlungsformen (Munich: Beck, 2006), 70. 
'asylum-fathers'. ${ }^{13}$ Predictably, Griesinger's demands for brain research and asylum reform met with considerable resistance, but in 1865 he earned the chance to put some of his ideas to work. He was appointed to the first academic chair of psychiatry and nervous diseases established at the University of Berlin and promptly set about lobbying for the institutional and pedagogical reforms which he believed would give psychiatry a rightful place alongside other specialties considered part of a new scientific medicine. ${ }^{14}$

Only three years into his appointment Griesinger died. Although he had been able to carry out several of the reforms, including the creation of new research-oriented clinics in various universities, he did not contribute as much in the way of original research on the specific anatomical causes of mental illness. ${ }^{15}$ However, he had galvanised a new generation in such a pursuit, and one of the young physicians so motivated by Griesinger's ambitious vision was Theodor Meynert. Where Griesinger may have neglected to pinpoint the precise relationship between brain disease and mental illness, Meynert excelled. ${ }^{16}$ It was here in connection with forwarding psychiatric research on the basis of neuropathology that Meynert conspicuously led the way in the latter half of the nineteenth century, helping shape the future of the discipline through students such as Carl Wernicke, August Forel and Sigmund Freud. ${ }^{17}$

The year Griesinger was appointed to the new chair in Berlin, Meynert joined the medical faculty in Vienna as a lecturer on 'The Structure and Function of the Brain and Spinal Cord'. ${ }^{18}$ For several years, he had worked as an assistant physician at the Imperial Asylum, where he also performed autopsies on the patients who died there. As a result, he developed his skill in pathological anatomy with a specific focus on the brain and nervous tissues. Now in the position as instructor as well as clinical pathologist, he was groomed by Rokitansky, who by then had become University Rector, to lead research on the brain from within the ranks of the academy. ${ }^{19}$ In a short time, he was appointed to the new chair

13 Ackerknecht, Kurze Geschichte der Psychiatrie, op. cit. (note 10), 59; Engstrom, op. cit. (note 10), 54-8; George Weisz, Divide and Conquer: A Comparative History of Medical Specialization (Oxford: Oxford University Press, 2006), 53-4.

14 The notion of 'scientific medicine' had been in circulation for some time. Some argue the difference around the 1860s was a matter of state funding of research institutes. John Harley Warner, 'Science in Medicine', Osiris, 1 (1985), 37-58; William Coleman and Frederic Lawrence Holmes, The Investigative Enterprise: Experimental Physiology in Nineteenth-Century Medicine (Berkeley, CA: University of California Press, 1988); Timothy Lenoir, The Strategy of Life: Teleology and Mechanics in Nineteenth-Century German Biology (Chicago, IL: University of Chicago, 1989).

${ }^{15}$ Franz Nissl, 'Über die Entwicklung der Psychiatrie in den letzten 50 Jahren', Verhandlungen des Naturhistorisch-Medizinischen Vereins, 8 (1908), 511; Marx, op. cit. (note 4), 361; Hagner, op. cit. (note 10), 257.

${ }^{16}$ Helmut Gröger, 'Zur Entwicklung der Psychiatrie in der Wiener Medizinischen Schule', in Brigitta Keintzel and Eberhard Gabriel (eds), Gründe der Seele: Die Wiener Psychiatrie im 20. Jahrhundert (Vienna: Picus, 1999), 34-5; Heini Hakosalo, 'The Brain Under the Knife: Serial Sectioning and the Development of Late NineteenthCentury Neuroanatomy', Studies in History and Philosophy of Science Part C: Studies in History and Philosophy of Biological and Biomedical Sciences, 37, 2 (June 2006), 179-80.

${ }^{17}$ Eulner, op. cit. (note 12), 276; Katja Guenther, 'Recasting Neuropsychiatry: Freud's "Critical Introduction" and the Convergence of French and German Brain Science', Psychoanalysis and History, 14, 2 (2012), $208-10$.

18 Marx, op. cit. (note 4), 362; Johnston, op. cit. (note 10), 224; Lesky, op. cit. (note 4), 339; Franz Seitelberger, 'Theodor Meynert (1833-92), Pioneer and Visionary of Brain Research', Journal of the History of the Neurosciences, 6, 3 (December 1997), 266; T. Meißel, 'Freud und die österreichische Psychiatrie seiner Zeit', in Heinz Böker (ed.), Psychoanalyse und Psychiatrie: Geschichte, Krankheitsmodelle und Therapiepraxis (Berlin: Springer, 2006), 54.

${ }^{19}$ Eulner, op. cit. (note 12), 276; Lesky, op. cit. (note 4), 107-9. 
of psychiatry in 1870, the first such position in the entire Austro-Hungarian Empire and only the second after Griesinger in all of German-speaking Europe. ${ }^{20}$

Meynert's academic success and ultimately his leadership of the new anatomically oriented psychiatry, later dubbed 'brain psychiatry', ${ }^{21}$ hinged precisely on his ability to dissect post-mortem human tissue and to detect signs of disease, or structural damage and organic decay, that would suggest the neuropathological basis of mental illness. The fact that he became a psychiatrist on this basis, not strictly by any specialty training but by forging and melding his own formation from a general education in medicine and pathological anatomy, underscores that Meynert was able to play an instrumental role in giving psychiatry new shape, steering it to become in his words 'an exact psychiatric science'. ${ }^{22}$

\section{Connecting Fibre-Systems}

Meynert's leadership of the new academic discipline of psychiatry was due not only to his institutional authority but also his continued anatomical and pathological study of the nervous system. If his accelerated rise in the academy was in part thanks to Rokitansky's patronage, it was equally in recognition of his penetrating research on the brain and nerves, specifically, his delineation of three kinds of nerve fibres comprising what he called the projection, callosal and association fibre-systems. ${ }^{23}$ Although there has been a tendency to credit Meynert somewhat exclusively for the differentiation of fibres in the brain, his delineation of their functions indisputably shaped neuro-anatomical and -physiological research in the 1870 s and 1880 s. $^{24}$ Why this was so is the question driving this section.

${ }^{20}$ Leopold Schönbauer, Das medizinische Wien: Geschichte, Werden, Würdigung (Urban \& Schwarzenberg, 1944), 340-1; Eulner, op. cit. (note 12), 276-7; Johnston, op. cit. (note 10), 231; Lesky, op. cit. (note 4), 159, 340-1; Gröger, op. cit. (note 16), 34-5; Peter J. Whitehouse, Konrad Maurer and Jesse F. Ballenger, Concepts of Alzheimer Disease: Biological, Clinical, and Cultural Perspectives (Baltimore, MD: Johns Hopkins University Press, 2000), 296; Weisz, op. cit. (note 13), 53.

${ }^{21}$ Ackerknecht, Kurze Geschichte der Psychiatrie, op. cit. (note 10), 69, 77; Erwin Heinz Ackerknecht, A Short History of Psychiatry (New York: Hafner, 1968), 71; Ackerknecht, 'Gudden, Huguenin, Hitzig',op. cit. (note 10), 68.

22 Theodor Meynert, 'Über die Nothwendigkeit und Tragweite einer anatomischen Richtung in der Psychiatrie', Wiener medizinische Wochenschrift 18 (May 3, 1868), 575.

${ }^{23}$ Meynert did not explicitly use the term 'projection fibre-system' [Projectionsfasersystem] until 1869, but he did refer more generally to 'fibre-systems' which he described as 'projecting' [projiciirt] as early as 1865. Theodor Meynert, 'Neue Untersuchungen über den Bau der Grosshirnrinde und seine örtlichen Verschiedenheiten: Vortrag, gehalten in der Sitzung der k.k. Gesellschaft der Ärzte am 20. November 1868', Medizinische Jahrbücher, 17 (1869), 15; Theodor Meynert, 'Anatomie der Hirnrinde als Träger des Vorstellungslebens und ihrer Verbindungsbahnen mit den empfindenden Oberflächen und den bewegenden Massen', in Maximilian Leidesdorf (ed.), Lehrbuch der psychischen Krankheiten (Erlangen: Enke, 1865), 61; Theodor Meynert, 'Ein Fall von Sprachstörung anatomisch begründet', Medizinische Jahrbücher, 22 (1866), 179.

${ }^{24}$ Ackerknecht, A Short History of Psychiatry, op. cit. (note 21), 69; Lesky, op. cit. (note 4), 337; H.A. Whitaker and S.C. Etlinger, 'Theodor Meynert's Contribution to Classical 19th Century Aphasia Studies', Brain and Language, 45, 4 (November 1993), 567; Seitelberger, op. cit. (note 18), 264; Gröger, op. cit. (note 16), 34; Cornelius Borck, 'Fühlfäden und Fangarme: Metaphern des Organischen als Dispositiv der Hirnforschung', in Michael Hagner (ed.), Ecce cortex? Beiträge zur Geschichte des modernen Gehirns (Göttingen: Wallstein, 1999), 151-2; Michael Hagner, 'Cultivating the Cortex in German Neuroanatomy', Science in Context, 14, 04 (2001), 544; Hakosalo, op. cit. (note 16), 173; Guenther, op. cit. (note 17), 217-9; Young, op. cit. (note 6); Hagner, op. cit. (note 10); Jeremy D. Schmahmann and Deepak N. Pandya, 'Cerebral White Matter: Historical Evolution of Facts and Notions Concerning the Organization of the Fiber Pathways of the Brain', Journal of the History of the Neurosciences, 16, 3 (July 10, 2007), 237-67. 
I argue that while neither his method of dissection nor most of his anatomical descriptions was completely original, the way he was able to connect what he saw inside the brain with an image of what he described as 'inside' the mind worked precisely because of his combination of material and metaphorical techniques. In what follows, I will analyse two of Meynert's earliest publications, one from the same year he joined the medical faculty in Vienna and the other a case history from the following year, 1866, which he initially delivered as a presentation to the Imperial-Royal Society of Physicians. ${ }^{25}$ These two works represent a critical window on Meynert's early development of his theory of brain function, although they are often overlooked with few exceptions in relation to his larger body of texts published after he became the full Professor of Psychiatry in $1870 .{ }^{26}$ In order to appreciate the effectiveness of his research, however, these early publications merit special attention, particularly as they provide some of his most vivid and detailed descriptions of the brain's composition. To start, I will introduce some of the basic features of the first publication on the 'Anatomy of the Cortex', culminating in his brief sketch of how consciousness emerged from within the brain. Then, I will shift to discuss his 'Case of a Speech Disturbance', paying special attention to his elaboration of language functions along discrete pathways of brain fibre.

\section{Anatomy of the Cortex}

From the opening lines of his chapter on cerebral anatomy, which appeared in a textbook of psychiatry by his colleague Maximilian Leidesdorf in 1865, Meynert laid out the fundamental aim of brain research for psychiatrists, namely, to discern the separate forms of mental disturbance from a more general variety of mental disorder, or insanity [Blödsinn]. He spoke of different 'organs' inside the brain which gave rise to basic mental representations [Vorstellungen] in 'central parts' [Centraltheile] of the cortex. But the lesson he drew was that damage to one part did not necessarily entail damage to all. Some aspects of the mind, or what he referred to collectively as the life of ideas' [Vorstellungsleben], could remain completely intact despite the fact that some of its 'intermediary organs' [vermittelnden Organe] were destroyed. The result might be a certain degree of 'strangulation' [Abschnürung] or cutting off of specific 'idea-centres' [Vorstellungscentren] but overall the life of the mind remained 'undisturbed' ${ }^{27}$

In this serpentine first sentence, Meynert was already making a claim to the basic principle of specificity, that is, the specificity of organs, even parts of organs, in relation to the specificity of disease. Such principle of mutual organic-pathological specificity was critical to Meynert and others hoping to demonstrate the scientific merit of psychiatric research when allied with the anatomical-pathological study of the brain. ${ }^{28}$ If certain parts of the brain serving certain 'idea-centres' of the mind could be cut off or 'strangulated'

\footnotetext{
${ }^{25}$ Meynert, 'Anatomie der Hirnrinde', op. cit. (note 23); Meynert, 'Ein Fall von Sprachstörung', op. cit. (note 23).

${ }^{26}$ Hagner, Hakosalo and Guenther each address the two publications, while Eling, Whitaker and Etlinger devote the most attention thus far to the 1866 case study. Hagner, op. cit. (note 10), 270-1; Hakosalo, op. cit. (note 16), 175; Katja Guenther, Localization and its Discontents: A Genealogy of Psychoanalysis and the Neuro Disciplines (Chicago: University of Chicago Press, 2015), 24; Whitaker and Etlinger, op. cit. (note 24); Paul Eling, 'Meynert on Wernicke's Aphasia', Cortex, 42 (2006), 811-16.

27 Meynert, 'Anatomie der Hirnrinde', op. cit. (note 23), 45.

${ }^{28}$ Charles Rosenberg, 'What Is Disease? In Memory of Owsei Temkin', Bulletin of the History of Medicine, 77, 3 (2003), 496-8; Weisz, op. cit. (note 13), 51; George Rosen, The Specialization of Medicine with Particular Reference to Ophthalmology, Medicine \& Society in America (New York: Arno Press, 1972), 15; W. Schmitt, 'Das Modell der Naturwissenschaft in der Psychiatrie im Übergang vom 19. zum 20. Jahrhundert', Berichte zur Wissenschaftsgeschichte, 6, 1-4 (1983), 90; Ackerknecht, Kurze Geschichte der Psychiatrie, op. cit.
} 
from the rest, without being affected, then not only did this indicate an important division of brain function but also a degree of separation between certain mental disturbances and all-out mental illness. ${ }^{29}$ In other words, such specificity potentially expanded the remit of psychiatric research from conspicuous mental disorder to virtually any disturbance distally affecting the mind. ${ }^{30}$ It was a pivotal part of the bid to make psychiatry scientific, to make it 'exact' and 'precise'. ${ }^{31}$ What I want to focus on, though, is how Meynert managed it, that is, how he developed the thesis of such specificity with respect to the brain and nerves. As a clue, the key lay in the latter. Nerve fibres were for Meynert the critical link to understanding brain function. ${ }^{32}$ Following their paths was prelude to finding their purpose.

To appreciate Meynert's emphasis on the role of nerve fibres inside the brain, one need look no farther than the full title of his chapter, 'Anatomy of the Cortex as the Carrier of the Life of Ideas and its Pathways of Connection with the Sensory Surfaces and Moving Masses' ${ }^{33}$ For Meynert, the outer layer of the brain, the cortex, contained or carried out the life of ideas or mental representations. But those ideas formed there only with the help of specific pathways that connected the cortex to the rest of the nervous system. Only because of pathways connecting the brain to the rest of the body, and indeed to the world, were ideas able to form at the outer limits of the nervous system in the 'grey bed' of cortical tissue covering the brain. ${ }^{34}$ 'Anatomical pathways' [anatomische Bahnen], therefore, were the essential meld of structure and function. ${ }^{35}$ They formed the basis in which the life of the mind was carried, or better, carried out, through the life of the brain. ${ }^{36}$

But how could Meynert determine such activity or connectivity in dead brain tissue? What qualified anyway as a pathway? To understand this requires a closer inspection of

(note 10), 71; Michel Foucault, Maladie mentale et psychologie, 2nd edn, Quadrige 198 (1954; repr., Paris: Presses universitaires de France, 1997), 11.

29 The 'therapeutic and epistemological payoff' of cerebral localisation and clinical localisation were never far apart. Richard C. Sha, Perverse Romanticism: Aesthetics and Sexuality in Britain, 1750-1832 (Baltimore, MD: Johns Hopkins University Press, 2009), 53-8; Anne Harrington, 'The brain and behavioral sciences', in Peter Bowler and John Pickstone (eds), The Cambridge History of Science, Vol. 6 (Cambridge: Cambridge University Press, 2009), 510-3; Hagner, op. cit. (note 10); Susan Leigh Star, Regions of the Mind: Brain Research and the Quest for Scientific Certainty (Stanford, CA: Stanford University Press, 1989); Anne Harrington, 'Psychiatrie und die Geschichte der Lokalisation geistiger Funktionen', Nervenarzt, 60, 10 (1989), 603-11; Young, op. cit. (note 6).

${ }^{30}$ For discussion of the social perils yet sociological power of diagnostic specificity in early psychiatry, see Jan Goldstein's trenchant analysis of the concept of 'monomania' in, Jan Goldstein, Console and Classify: The French Psychiatric Profession in the Nineteenth Century, 2nd edn (Cambridge: Cambridge University Press, 1987; Chicago, IL: University of Chicago Press, 2001), ch. 5, passim.

31 On the cultural virtues of scientific precision in late nineteenth-century Vienna, see Deborah R. Coen, 'Living Precisely in Fin-de-Siècle Vienna', Journal of the History of Biology, 39, 3 (2006), 493-523. For satirical musings on the moral paradox of rhetorical overtures to precision, see Robert Musil, Precision and Soul: Essays and Addresses, trans. Burton Pike and David S. Luft (Chicago, IL: University of Chicago Press, 1990).

32 Clarke, Rousseau and more recently Martensen and Bassiri have examined the significance of fibre morphology for early modern theories of brain function, while Guenther and Borck discuss its particular salience for Meynert. Edwin Clarke, 'The Doctrine of the Hollow Nerve in the Seventeenth and Eighteenth Centuries', Medicine, Science and Culture: Historical Essays in Honor of Owsei Temkin, 1968, 123-41; Rousseau, 'Nerves, spirits and fibres', op. cit. (note 6); Martensen, op. cit. (note 6), 84-9; Bassiri, op. cit. (note 6); Borck, op. cit. (note 24); Guenther, op. cit. (note 4), ch. 1.

${ }_{33}$ Meynert, 'Anatomie der Hirnrinde', op. cit. (note 23).

34 Ibid., 59.

35 Ibid., 61.

${ }^{36}$ Meynert's use of the word Träger is interesting because it can denote either something which carries or contains an object in a static, supportive fashion or something which carries out, executes, or enables an activity. 
his method of dissection. And the method that helped Meynert most to discern such pathlike structures was known as Abfaserung or 'de-fibering'. ${ }^{37}$ Using a pair of tweezers or a needle, he gently scraped away the soft tissue of the brain in order to expose its fibrous interior. Initially practised by Karl Friedrich Burdach in the early decades of the nineteenth century, it was gradually abandoned by most anatomists because it demanded immense patience and skill to pull apart the fragile strands of tissue without damaging or severing them. ${ }^{38}$ Meynert, however, considering Burdach's research of 'the most essential value', mastered the technique. ${ }^{39}$ Because few others practised it by the 1860 s, he was able to detect and depict different features inside the brain, specifically long tracts of fibre, arguing that they constituted both a 'morphological' and 'physiological connection', that is, both the structures of material support and functional communication. ${ }^{40}$ It was not simply that Burdach's technique revealed to Meynert the brain was made up of fibre-like paths (or path-like fibres), but rather by cutting or 'de-fibering' the brain this way, he effectively shaped or 're-fibered' it thus. The act of cutting into the brain material was also a way of re-constituting it. ${ }^{41}$

If Meynert's technique of dissecting the brain was in part productive of its path-like appearance, so was his technique of describing the material tissue. While the de-fibering method enabled him to follow out the strands of tissue deep into the brain and back out onto its cortical surface, then his means of depicting those strands and their trajectories helped him delineate their functions. Out of the 'thicket' of fibre deep inside the 'inner core' or 'pith' [innere Gewebe] of the brain, he detected different bundles or sheaves [Bündel] of 'thread-like' [fädenformige] fibres that came together like 'cords' [Kette] or bands of string and then 'projected' [projicirt] along different 'lines' [Züge or Projectionslinien] through the brain. ${ }^{42}$ By their many ramifications and radiations, like 'streams of light' or 'branches' of trees, these 'wandering masses of fibre' [wendende Fasermasse] culminated or were 'filled out' [Erfüllung] across the 'surface of the brain-mantle' [Fläche der Hirnmantel]. Taken together, such branching thread-like fibres wove a 'web' [Gewebe] that Meynert collectively referred to as the 'connecting systems' [verknüpfendenen Systems] of the brain and nerves, later designated as the projection, association and callosal fibre-systems. ${ }^{43}$

The novelty of Meynert's research hinged on this delineation. Specifically, it hinged on a more fundamental designation of fibres as pathways with different purposes. Others before

\footnotetext{
37 The historian Heini Hakosalo provides an excellent discussion of the intricacies and difficulties of Meynert's methods of dissection: Hakosalo, op. cit. (note 16). See also Borck, op. cit. (note 24); Hagner, op. cit. (note 24); Guenther, op. cit. (note 4).

${ }^{38}$ Hakosalo, op. cit. (note 16), 179-91; Hagner, op. cit. (note 10), 202-3. For discussion of Burdach who introduced the terms 'morphology' and 'biology', see Lynn K. Nyhart, Biology Takes Form: Animal Morphology and the German Universities, 1800-1900 (Chicago, IL: University of Chicago Press, 1995), 35-6.

${ }^{39}$ Meynert, 'Anatomie der Hirnrinde', op. cit. (note 23), 72; Meynert, 'Ein Fall von Sprachstörung', op. cit. (note 23), 156

40 Meynert, 'Ein Fall von Sprachstörung', op. cit. (note 23), 177, 181.

${ }^{41}$ For more on the conceptual-empirical sculpting of instruments, see Erna Fiorentini, 'Inducing Visibilities: An Attempt at Santiago Ramón y Cajal's Aesthetic Epistemology', Studies in History and Philosophy of Science, Part C: Studies in History and Philosophy of Biological and Biomedical Sciences, 42,4 (2011), 391-94; J. Schickore, The Microscope and the Eye: A History of Reflections, 1740-1870 (Chicago, IL: University of Chicago Press, 2007). For more reflection on the material-technical constitution of phenomena, see Hans-Jörg Rheinberger, 'Gaston Bachelard and the Notion of "Phenomenotechnique", Perspectives in Science, 13, 3 (2005), 313-28; Robert G. Frank, 'Instruments, Nerve Action, and the All-or-None Principle', Osiris, 9 (1994), 208-35.

42 Meynert, 'Anatomie der Hirnrinde', op. cit. (note 23), 49, 51, 61, 68; Meynert, 'Ein Fall von Sprachstörung', op. cit. (note 23), 156.

${ }^{43}$ Meynert, 'Anatomie der Hirnrinde', op. cit. (note 23), 46, 49-50.
} 
him had also identified fibres in the brain, but the key difference was that he imaginatively fleshed them out and traced them deep inside the tissue. Both materially and discursively, he elaborated on them and he elaborated in them. For even though the language of fibres and paths was already part of what the historian of medicine Erna Lesky called the 'new plastic' anatomical vocabulary, Meynert re-shaped that plastic imagery to new ends. ${ }^{44}$ In describing the system of fibres confined to the cortex, for example, he proclaimed them as the 'morphological substrate' of all connections between images and ideas, memories and judgments, indeed, all the connections that ever 'entered' the 'contents of consciousness'. ${ }^{45}$ These were the critical 'associations' of ideas which comprised the mind and 'became conscious' or were 'made conscious' once they were pulled 'like a thread' across its 'threshold'. 46

This imagery of connecting fibres, branches and threads was integral to Meynert's account of how both the brain and mind worked, and the imagery itself worked because it blurred the difference between material form and mental function. ${ }^{47}$ It intimated a distinction between inner and outer, centre and periphery and lower and higher, but like lines without spatial dimension, only direction, the image of fibres potentially flattened these distinctions. Thread-like, they seemed able to pull thoughts across some subconscious threshold. Only it was never clear which were the threads, the fibres or the thoughts themselves, and what was pulling what. But even if such imagery was ambiguous, it was nevertheless useful. Like the technique of dissection, Meynert's tactics of description were in part constitutive of the phenomenon. Yet like the tissue itself, these tactical images were not easily pulled apart.

For Meynert, such enmeshed imagery helped to flesh out not only the material composition of the brain but also to predict its lines of decomposition. Just as the nerve fibres carried out the contents of the mind along thread-like paths, those fibres, like threads, could come undone. And when they did, the fabric of the mind would unravel.

\section{Meynert's Case Study}

In 1866, Meynert published his first case history based on a presentation given before the Imperial-Royal Society of Physicians earlier that year. ${ }^{48}$ It would be one of the first demonstrations of how psychiatrists could make use of anatomical dissection of the brain to account for an isolated mental disturbance in terms of fibre pathways. Although it was initially hailed as one of the first anatomical descriptions of the trajectory of the auditory nerve from the inner ear through the midbrain and finally to the outer cortex, it is generally

\footnotetext{
${ }^{44}$ Lesky, op. cit. (note 4), 108.

45 Meynert, 'Anatomie der Hirnrinde', op. cit. (note 23), 46, 54, 71.

46 'Durch diese rechtwinklig verschiedene Verlaufsrichtung sind die Fasern des Zwingensystems geeignet, sich mit den Fasern des Stabkranzbalkensystems in den Hirnrindezellen zu verknüpfen, so wie in einem Gewebe der Einschlagsfaden sich mit der Kette von Fäden verknüpft, mit denen er sich kreuzt.' Ibid., 50-1.

${ }^{47}$ Figlio and Bassiri each provide excellent discussion of other examples of such morphological effacement. Karl Figlio, 'The Metaphor of Organization: An Historiographical Perspective on the Bio-Medical Sciences of the Early Nineteenth Century', History of Science, 14 (1976), 17-53; Bassiri, op. cit. (note 6).

${ }^{48}$ Meynert, 'Ein Fall von Sprachstörung', op. cit. (note 23); Theodor Meynert, 'Anatomische Begründung gewisser Arten von Sprachstörungen', Österreichische Zeitschrift für praktische Heilkunde, February 16, 1866, 199-200; Theodor Meynert, 'Anatomische Begründung gewisser Fälle von Sprachstörungen', Wochenblatt der Zeitschrift der k.k. Gesellschaft der Ärzte in Wien, 1866, 129-30; Theodor Meynert, 'Über einen Fall von Sprachstörung', Wiener medizinische Wochenschrift, 16 (16 February 1866), 257-58.
} 
less acknowledged as one of the first clinical descriptions of a new type of language disorder. $^{49}$

A young woman, twenty-three years of age, had fallen ill due to what appeared to have been constricted blood flow in her aorta. In particular, she had trouble speaking or what Meynert described as the 'inhibition of verbal expression' ${ }^{50}$ For example, she repeatedly mispronounced the word for 'cough' (Hutzen instead of Husten) and confused the words for 'head' and 'hand'. When asked to repeat the word 'hand', she said 'yellow' instead. ${ }^{51}$ It was as if, according to Meynert, she not only had trouble speaking but also to some extent hearing. He noticed especially how often she failed to realise that what she said made little sense and 'bore absolutely no relation to what she was trying to say'. ${ }^{52}$ Instead of recognising her 'erroneous verbal expressions', they entirely 'escaped' [entschülpften] her attention, as though they had never entered consciousness. ${ }^{53}$

Two weeks later, the patient died, affording Meynert the opportunity to perform an autopsy on her brain. What he found was a series of soft spots in a swollen area of discoloured tissue near the Sylvian fissure, a deep groove of tissue separating the frontal and the temporal lobes. ${ }^{54} \mathrm{He}$ dubbed this inner fold of tissue the 'sound field' [Klangfeld] or the cortical area where mental representations of sounds, including speech, were formed. ${ }^{55}$ Either the patient's trouble with speaking had been a result of her no longer being able to form the correct mental representations of the sounds of words or the mental representations she had were no longer connected with her memories, specifically the 'memory-images' [Erinnerungsbilder] of those sounds of words. ${ }^{56}$

Normally during the course of speech, he explained, sounds of words entered the body through nerve endings lining the labyrinth of the inner ear. They activated the nerves by way of 'vibrations' [Schwingungen], becoming 'sensory impressions' [Sinneseindrücke]. ${ }^{57}$ These impressions or sensations then travelled along the pathways of fibres which converged in a 'bundle' [Bündel] that Meynert dubbed the 'acoustic cord' [Acusticusstrang]. ${ }^{58}$ Along the way, they turned into 'images', or the basic mental units of sound [Klangbilder]. ${ }^{59}$ As these 'sound-images' continued along the pathways of fibre, they eventually arrived at the 'sound-field'. There they were connected via different fibres to 'word-images' [Wortbilder] as well as 'memory-images'. ${ }^{60}$ In sum, this was the anatomical route of 'speech comprehension' [Sprachverständniss]. ${ }^{61}$ But in the case

\footnotetext{
49 Whitaker and Etlinger, op. cit. (note 24), 572; Seitelberger, op. cit. (note 18), 268; Hagner, op. cit. (note 10), 269-70; cf. Eling, op. cit. (note 26), 814.

${ }^{50}$ Meynert, 'Ein Fall von Sprachstörung', op. cit. (note 23), 154.

51 Ibid.

52 Ibid.

53 Ibid.

54 Ibid., 155

55 Ibid., 182-4.

56 Ibid., 167; Whitaker and Etlinger, op. cit. (note 24), 565.

57 Such aural and oscillating account of perception was by no means new, however. Meynert, 'Ein Fall von Sprachstörung', op. cit. (note 23), 152; Lange, op. cit. (note 1), 368; Hugh W. Buckingham and Stanley Finger, 'David Hartley's Psychobiological Associationism and the Legacy of Aristotle', Journal of the History of the Neurosciences, 6, 1 (1997), 21-37; Veit Erlmann, Reason and Resonance: A History of Modern Aurality (New York: Zone Books, 2010).

58 Meynert, 'Ein Fall von Sprachstörung', op. cit. (note 23), 169, 174, 183.

59 Ibid., 166.

${ }^{60}$ Ibid., 166-70.

${ }^{61}$ It would be another two years until he explicitly emphasised the role of understanding as such. Meynert, 'Neue Untersuchungen', op. cit. (note 23), 23.
} 
of the young woman, a part of that route had been disrupted. Part of the 'sensory chain' [sensorische Kette] in her brain was 'disconnected'. ${ }^{62}$

A similar case of speech disorder had already been described in France by the anatomistcum-anthropologist Paul Broca. In 1861, he declared to have discovered the 'seat' of articulate speech in the third convolution of the left frontal cortex. ${ }^{63}$ The patient, Monsieur Leborgne, was nicknamed 'Tan' because that was virtually the only sound he could make. When he died Broca inspected Leborgne's brain in search of signs of damage or disease and identified a relatively isolated area of decayed tissue near the posterior region of the frontal cortex, across from the Sylvian fissure. This was where, he deduced, the 'faculty' of speech resided, that is, the mental capacity to execute and coordinate the movement in the muscles of the face, mouth and throat to produce coherent spoken language. The distinction was critical for Broca to uphold between language in general and the function of articulation, for basically it amounted to a difference between mind and muscle. While he ruled out the possibility of direct muscular paralysis, he attempted to avoid the rough equation of language tout court with just this one area of the brain. Instead, his anatomical 'localisation' was more nuanced. He only proposed that this area was responsible for the planning and execution of movements related to speaking, that is, the 'ideational' basis of articulation. ${ }^{64}$

Not only was this nuance critical to avoid offending the sensibilities of some of the French élite, but it also exposed a certain conceptual gap that Meynert would try to fill. Whereas for Broca, the speech disorder that came to be known as 'aphasia' involved strictly the problem of articulation, for Meynert it could also entail problems with comprehension. At least, he believed that was the case with the young woman. Not only did she fail to express herself properly, but she failed to realise her failure. The fact that her errors 'escaped' her notice suggested to Meynert that, on some level, she never really 'heard' them in the first place. ${ }^{65}$

At this point it should be emphasised that Meynert did not appear to be proposing a whole new language disorder but rather an added dimension to the aphasia Broca had already described. The reason to draw this distinction is that one of Meynert's students, Carl Wernicke, would later re-parcel Meynert's emphasis on the sensory aspect of speech perception into a new and distinct form of aphasia separate from Broca's. In 1874, Wernicke published a large study featuring several of his own case histories of aphasia, including some which involved Broca's aphasia of articulation, re-classified as 'motor aphasia', and a new type he characterised as 'sensory'. ${ }^{66}$ From the beginning of his paper, he was very clear about his reliance on Meynert's research, openly declaring, '[E]verything of value in the present study is ultimately based on Meynert's work.' ${ }^{67}$ Nevertheless, for

\footnotetext{
62 Meynert, 'Ein Fall von Sprachstörung', op. cit. (note 23), 167-9.

63 Paul Broca, 'Remarques sur le siège de la faculté du langage articulé, suivies d'une observation d'aphémie (perte de la parole)', Bulletins de la Société Anatomique, 36 (1861), 330-57; Anne Harrington, Medicine, Mind, and the Double Brain: A Study in Nineteenth-Century Thought (Princeton, NJ: Princeton University Press, 1987), ch. 2 .

${ }^{64}$ Harrington, op. cit. (note 63), 40-5; Hagner, op. cit. (note 10), 265-8; Young, op. cit. (note 6), 140-6.

65 Whitaker and Etlinger, op. cit. (note 24), 561; Hagner, op. cit. (note 10), 270; Eling, op. cit. (note 26), 813.

${ }^{66}$ Carl Wernicke, Der aphasische Symptomencomplex: Eine psychologische Studie auf anatomischer Basis (Breslau: Cohn \& Weigert, 1874); Carl Wernicke, 'The aphasic symptom-complex: A psychological study on an anatomical basis', trans. in R.S. Cohen and Marx W. Wartofsky (eds), Proceedings of the Boston Colloquium for the Philosophy of Science, Boston Studies in the Philosophy of Science, 4 (1969), 34-97.

${ }^{67}$ Wernicke also conceded that his conception of sensory aphasia followed 'almost automatically' from Meynert's ideas. Wernicke, 'The aphasic symptom-complex', op. cit. (note 66), 34.
} 
reasons which would require a more dedicated discussion, Wernicke earned much of the credit. $^{68}$

Even though Meynert did not firmly differentiate between Broca's aphasia and his patient's speech disorder, the fact that he emphasised the sensory aspects of her dysfunction is an important clue to how he drew on a general philosophical understanding of the mind to elaborate the functions of the brain. If the language of fibres, cords and strings was by and large borrowed from Burdach and others, Meynert's references to 'memory-images' and the 'threshold of consciousness' reflected an ample infusion of the latest variety of 'associationism' promulgated by philosophical psychologists such as Gustav Fechner. By the middle of the nineteenth century, the theories of mental association had passed through at least two centuries of revision from Locke and Hume to Condillac and Comte before coming to Meynert probably through the writings of Lotze and Fechner. ${ }^{69}$ But it is likely that Fechner helped most of all to shape how Germanspeaking physicians and philosophers, physiologists and psychologists, thought about the mind in the late nineteenth century. ${ }^{70}$

Fechner, though adapting such terms as 'memory-images' from Johann Friedrich Herbart, Kant's successor in Königsberg, reworked many of the themes of associationism in his own Elements of Psychophysics published in $1860 .{ }^{71}$ Arguing that all psychological phenomena could be understood in the same way as mechanical phenomena, Fechner nevertheless deferred submitting to an outright materialism. Rather, he preferred to view the mind as the 'resultant' function of the brain but not ontologically equivalent to its material structures. ${ }^{72}$ His fellow colleague at Leipzig, Rudolf Hermann Lotze, had similarly attempted to sidestep a strict materialism in his own textbook published in 1858, Medical Psychology, or the Physiology of the Mind. ${ }^{73} \mathrm{He}$ also defended both physiological and psychological research but strictly on the grounds of a "neoKantian' distinction between the phenomenal 'appearances' or manifestations of mental activity and the 'essence' of the mind itself. While there was no way for science to know anything about the true essence of the mind, or even soul (in German, it was the same word, Seele), its activities and functions remained completely within bounds. $^{74}$

Fechner and Lotze were both reacting to some of the cruder varieties of scientific materialism still circulating since the liberals' defeat in 1848 . With their more circumspect and self-critical language about the mind and its relation to the brain, they provided

\footnotetext{
${ }^{68}$ Years after Meynert's death, Wernicke continued to acknowledge his debt: 'It is therefore evident that Meynert's works had already satisfied all the requirements for realization of a penetrating interpretation of aphasia. My, The Aphasia Symptom Complex, which appeared in 1874, merely contained a further development of Meynert's concepts and their special relation to human speech.' Carl Wernicke, Grundriss der Psychiatrie in klinischen Vorlesungen (Thieme, 1906).

${ }^{69}$ Jan Goldstein, The Post-Revolutionary Self: Politics and Psyche in France, 1750-1850 (Cambridge, MA: Harvard University Press, 2005), ch. 1, 3; Rousseau, 'Nerves, spirits and fibres', op. cit. (note 6), 83-111; Taylor, op. cit. (note 6), ch. 9; Anne Harrington, 'Beyond phrenology: Localization theory in the modern era', in The Enchanted Loom: Chapters in the History of Neuroscience (New York: Oxford University Press, 1991), $210-11$.

${ }^{70}$ Michael Heidelberger, Nature from Within: Gustav Theodor Fechner and His Psychophysical Worldview (Pittsburgh: University of Pittsburgh Press, 2004).

71 Gustav Theodor Fechner, Elemente der Psychophysik, vol. 1, 2 (Leipzig: Breitkopf und Härtel, 1860).

72 Heidelberger, op. cit. (note 70), 104.

${ }^{73}$ Rudolf Hermann Lotze, Medicinische Psychologie, oder, Physiologie der Seele (Leipzig: Weidmann'sche Buchhandlung, 1852).

${ }^{74}$ Ibid., 282, 495; Willey, op. cit. (note 4), 48.
} 
an outlet for researchers like Meynert to continue with their work. ${ }^{75}$ Thanks to Lotze and Fechner, Meynert was careful just enough to avoid collapsing the life of the mind into the life of the brain, preferring to frame the latter as the material 'vehicle' of the former, or the material 'ground' from which emerged the functions of the mind. Ideas and mental representations were 'carried out' or conducted by fibres which 'allowed for' their association. ${ }^{76}$ This was tentative language not only of a young academic aspirant but also an anatomically oriented psychiatrist who appreciated the philosophical and theological perils of roughly equating the mind and the brain. Still, despite such rhetorical restraint, Meynert did not avoid insinuating some degree of material continuity between the inner life of the mind and the inner structure of the brain. ${ }^{77}$ And the principal reason for this lay in his vivid elaboration of the fibres and the nerves, which, because he followed them like threads, led him to imagine the ideas themselves as such, indeed the whole of mental life as such: a web woven from the brain [Hirnschenkel], a mere 'physiological tabula rasa' made up of connections and paths. ${ }^{78}$

But this philosophical confusion was crucial to his clinical construction. ${ }^{79}$ Meynert considered all the higher mental functions as combined products of sensations and movements, at least the 'images' thereof, and so he accounted for his patient's speech disorder as both a matter of articulation and comprehension. She failed to speak properly not only because, like 'Tan', she lacked the requisite 'articulatory centre' but also because she lacked certain 'ideas of sound' [Klangvorstellungen]. ${ }^{80}$ This was most evident, Meynert maintained, because she failed to catch her own mistakes, that is, she no longer 'heard' her own incoherence. Either that, or it was because of the discoloured swelling of tissue in the 'field of sound'. In point of fact, the clinical-psychological description and the anatomicalpathological delineation were mutually reinforcing. They seemed to be self-implicating and entangled, which was part of what made Meynert's model compelling. The language of a mental disconnect prefigured that of a material one. What Meynert designated as 'loose threads' [losen Fäden] of fibre inside the brain extended to and were insinuated by some sense of unravelling connections somehow, somewhere 'inside' the mind. What this meant in terms of a more distributed and interconnected theory of cognition was of paramount importance. For, even by diffusing mental functions thus, along fibre nets, mesh, or webs, Meynert effectively reconstituted a material image of the mind.

\section{Bachelard's Material Imagination}

The basic appeal of Meynert's imagery of the brain fibres as specialised pathways of the mind drew on a powerful intuition, historical and cultural, that whatever the mind was it

\footnotetext{
75 Michael Hagner, 'Die elektrische Erregbarkeit des Gehirns', in Die Experimentalisierung des Lebens: Experimentalsysteme in den biologischen Wissenschaften 1850-1950 (Berlin: Akademie Verlag, 1993), 259-60; Hagner, op. cit. (note 4), 217-8; Engstrom, op. cit. (note 12), 778; Young, op. cit. (note 6), 233; Star, Regions of the Mind, 156.

76 Meynert, 'Anatomie der Hirnrinde', op. cit. (note 23), 52.

77 Meynert, 'Neue Untersuchungen', op. cit. (note 23), 13-4; Theodor Meynert, Über Fortschritte im Verständniss der krankhaften psychischen Gehirnzustände (Vienna: Braumüller, 1878), 80; Theodor Meynert, Psychiatrie: Klinik der Erkrankungen des Vorderhirns begründet auf dessen Bau, Leistungen und Ernährung (Vienna: Braumüller, 1884), 261.

78 Meynert, 'Ein Fall von Sprachstörung', op. cit. (note 23), 179.

${ }^{79}$ Marx, op. cit. (note 4), 364. Compare with Gellner on the fruits of confusion and the function of incoherence, Ernst Gellner, 'Concepts and society', in Cause and Meaning in the Social Sciences (London: Routledge \& Kegan Paul, 1973).

${ }^{80}$ Meynert, 'Ein Fall von Sprachstörung', op. cit. (note 23), 181.
} 
had to do with making connections and those connections were to some degree internal, taking place in some 'inner' sort of space. ${ }^{81}$ It was only in the mid-seventeenth century that such an inner space of the mind came to be elaborated within the inner solid tissues of the brain, above all, the intricate nerve fibres. ${ }^{82}$ Two centuries later, Meynert built upon and extended this intuition by further delineating and articulating the fibres in terms of separate functional systems and then collating them as the material concretion of a connectionmaking mind. He deepened the appeal of this basic image of the mind as one fleshed out inside the brain by imaginatively following it farther, retracing its wandering threads and recreating an even more intricate and seemingly more precise anatomical-physiological portrait of how the mind was made up, and broken down, along the lines of the brain.

The draw of his work, therefore, had to do with its level of depth and detail, or at least the intimation that he had been able to explore farther and see further into the brain. And the success of such an intimation of insight and depth depended in part on his description of the material, indeed, the 'imagination of the material'. This phrase comes from the French philosopher of science Gaston Bachelard who in the late 1930s attempted what he called a 'psychoanalysis' of scientific knowledge and the poetic imagination. ${ }^{83}$ He claimed that all objective knowledge was forged by way of a kind of 'repression' and 'rupture' against a more primitive state of mind, which he believed to be, though intrinsic to literary creativity, the source of scientific error and epistemological obstacles. ${ }^{84}$ Without fully subscribing to such a division, however, I propose to develop Bachelard's exploration of what he called the 'images of material', particularly, the material imagination of 'the inside', in relation to Meynert's imagery of the brain. ${ }^{85}$

Scholars have analysed Meynert's rather extensive use of metaphors, especially in his later work. The historian of science Michael Hagner discusses, for example, Meynert's comparison of the nervous system to the Austro-Hungarian Empire, in which the cortex represented the 'capital' and the rest of the brain, 'provinces' ${ }^{86}$ Elsewhere, Hagner notes, Meynert described the brain as a 'colony of living conscious beings' ${ }^{87}$ Such comparisons

${ }^{81}$ Olaf Breidbach, 'Die Innenwelt der Außenwelt: Weltkonstitution im Hirngewebe? Zur Konturierung einer Neuralen Ästhetik', in Olaf Breidbach and Karl Clausberg (eds),Video ergo sum: Repräsentation nach innen und aussen zwischen Kunst- und Neurowissenschaften, Interface, 4 (Hamburg: Hans-Bredow-Institut, 1999), 34-60; Jörn Buchner, 'Erregbare Gewebe: Zur Physiologie des “nervigen Menschen” um 1800', in Jan Broch et al. (eds), Netzwerke der Moderne: Erkundungen und Strategien (Würzburg: Königshausen \& Neumann, 2007), 279-98; Andrew Pickering, The Cybernetic Brain: Sketches of Another Future (Chicago, IL: University of Chicago Press, 2010); Daniel Heller-Roazen, The Inner Touch: Archaeology of a Sensation (New York: Zone Books, 2007); Alva Noë, Out of Our Heads: Why You Are Not Your Brain, and Other Lessons from the Biology of Consciousness (New York: Hill and Wang, 2009).

${ }^{82}$ Martensen, op. cit. (note 6); Rousseau, 'Nerves, spirits and fibres', op. cit. (note 6); Frank, op. cit. (note 6).

${ }^{83}$ Gaston Bachelard, La Formation de l'esprit scientifique; Contribution à une psychanalyse de la connaissance objective (Paris: Vrin, 1938); Gaston Bachelard, La psychanalyse du feu, 18th edn, Collection psychologie 7 (Paris: Gallimard, 1938).

${ }^{84}$ Disagreement persists among scholars of Bachelard as to the extent of opposition or complementarity between science and the imagination, objectivity and subjectivity, even concepts and images. Lecourt, op. cit. (note 8), 32; Dominique Lecourt, Marxism and Epistemology: Bachelard, Canguilhem and Foucault, trans. Ben Brewster (London: NLB, 1975), 7, 12, 26, 52; Jean Pierre Roy, Bachelard, ou, Le Concept contre l'image (Montréal: Presses de l'Université de Montréal, 1977), 50-1; Tiles, op. cit. (note 8), 198; Gaston Bachelard, On Poetic Imagination and Reverie: Selections from Gaston Bachelard, trans. Colette Gaudin, rev. edn (Dallas, TX: Spring Publications, 1987), xx; Chimisso, op. cit. (note 9), 208; Edward George Baring, 'The Young Derrida and French Philosophy, 1946-67' (Cambridge, MA: Harvard University, 2009), 150-1.

${ }^{85}$ Bachelard, La terre et les rêveries du repos,op. cit. (note 8), 8-12ff.

${ }^{86}$ Hagner, op. cit. (note 24), 545.

${ }^{87}$ Ibid. 
were not purely for provocation. In the case of the colony metaphor, Meynert insisted it was a literal description. The brain really was in a significant sense made up of a collection of different forms of conscious life. ${ }^{88}$ The medical historian Cornelius Borck draws similar conclusions. When Meynert compared the human nervous system to the 'feelers' and 'tentacles' of the amoeba and jellyfish, these were not 'mere' metaphors. ${ }^{89}$ For Meynert, they denoted actual anatomical features common to both the complex human being and some of the simplest of life forms. ${ }^{90}$ They expressed, in Borck's words, the 'physiological principle' that all life was 'organized the same from the inside out'. ${ }^{91}$ But, as Borck points out, even such ostensible equivalence could do polemical work. Indeed, no matter the degree of anatomical verisimilitude or morphological literalism, these shared terms implied a broader 'explanatory strategy', and that was to identify the biological basis of the mind..$^{92}$

Despite penetrating investigation of Meynert's political, biological and technological comparisons, few scholars have analysed Meynert's metaphors of the material itself. This is what I have endeavoured to do, focusing on his tactics of describing the nerve fibres in terms of 'thread-like' paths carrying out mental images in the brain and, like material threads, susceptible of loosening and tearing not only in the brain but equally in the mind. And it was this problematic preposition 'in' that Meynert, despite attempting to disperse it with his emphasis on fibres, could not ultimately escape, if only because of the basic spatial language of the brain composed of an inner core and outer crust, and the inner fibres condensed into bundles and bands, branches and roots with a ground beneath and surface above. ${ }^{93}$ Throughout his work, there was this back-and-forth, up-and-down, inand-out propulsion. No matter how carefully he elaborated the mind's functions therein, there always remained this problematic image of 'in'.

For Bachelard, images of interiority were basic to the imagination of material. In the second volume of his Earth series published in 1948, he described how certain dream-like states of mind, or 'reveries', before certain objects elicited the imagination of refuge and repose. Whether by contemplating the hidden centre of a seed or the creeping depths of roots, whether wandering the labyrinthine channels of an underground cave or pondering the undisclosed insides of one's own body, all these were 'material images' inviting the reverie of intimacy, depth and interiority. ${ }^{94}$ But they were not only suggestive. In some sense, these images were equally metaphorical and material. They conveyed a meaning beyond themselves and yet always seemed to implicate themselves in that meaning. ${ }^{95}$

\footnotetext{
88 Theodor Meynert, Sammlung von populär-wissenschaftlichen Vorträgen über den Bau und die Leistungen des Gehirns (Vienna, Braumüller, 1892), 205.

${ }^{89}$ Borck, op. cit. (note 24), 147.

${ }^{90}$ In honor of Rokitansky, Meynert proclaimed that the 'inner life of the amoeba' was co-extensive with that of the 'super-human' [das Uebermenschliche]. Meynert, Über Fortschritte, op. cit. (note 77), 80.

${ }^{91}$ Borck, op. cit. (note 24), 149.

92 Cornelius Borck, 'Toys are us: models and metaphors in the neurosciences', in Suparna Choudhury and Jan Slaby (eds), Critical Neuroscience: A Handbook of the Social and Cultural Contexts of Neuroscience (Blackwell Publishing, 2012), 170.

${ }^{93}$ Figlio probes what he calls the 'essential interiority' embedded or imbued in the metaphors of the body fabric, even its organisation. Figlio, op. cit. (note 47), 25, 38.

94 Bachelard, La terre et les rêveries du repos, op. cit. (note 8), 8, 14, 21.

95 Ibid., 9, 205, 245-6; Bachelard, op. cit. (note 84), xxi-ii, xvi. Compare Roy and Blumenberg on 'pure' images and 'absolute metaphors', respectively. Roy, op. cit. (note 84), 50-3; Hans Blumenberg, Paradigms for a Metaphorology, Signale: Modern German Letters, Cultures, and Thought (Ithaca, NY: Cornell University Press, 2010), 3 .
} 
Meynert invoked such material-metaphors of depth and interiority in his language of the wandering fibre-masses in the brain and winding pathways in the mind, using them in turn as anatomical elaborations and psychological explanations. While evocative of woven fabric or growing roots, these images of fibre, thread, limb and stem, were nevertheless literal, material, anatomical designations of the brain's 'knotty' makeup. ${ }^{96}$ And yet, they functioned as the imagined conduits for the material elaboration of the mind he was cautious to provide. Material images of 'mental images' [Bilder], they worked less by explanation than by insinuation. That was what made Meynert's morphological model of the brain so powerful, so object-oriented, that it seemed to efface the difference between anatomy and image, material and metaphor. ${ }^{97}$ The fibre, both as a form of physical connection and mental conduction, served to unite structure and function, brain and mind.

And what if Bachelard were right? What if Meynert's images of the material could not help but be insinuated into the language of the mind? Would this mean he was captive to the purported universal dynamics of the imagination? Or was he perhaps simply redeploying historical discursive conventions of framing the mind in terms of the brain? I am not persuaded of either. Each scenario fails to account for the particular impact Meynert had on subsequent models of the brain and, for that matter, on philosophical ideas about the mind. One could be forgiven for imputing such an impact to a confluence of the institutional clout of science, the intellectual currents of materialism, and the dogged if desperate hope of delivering humanity from mental illness. But that would arguably still miss part of the point and much of the punch to Meynert's particular theories about the functions of fibre-paths. No doubt, these other connections were indissociable from the coherence of Meynert's work, but what I want to suggest is that his anatomicalphysiological imagination of pathways in the brain re-entrenched a much older intuition about the 'innerness' of the mind.

While Bachelard believed that the image of interiority was integral to the unconscious, others have recently argued that it is itself an historical artefact of modern thought. In as much as it may seem inevitable to think of mental features as 'inner', even this has cultural roots, as it were, tracing back at least to Augustine, if not before. ${ }^{98}$ If so, Bachelard's alleged distinction between objective science and the poetic imagination would need modification. Although he maintained that features of the imagination were intrinsic to the mind, he also claimed by contrast that the development of scientific knowledge demanded a degree of breaking with the imagination: 'When we turn inwards upon ourselves we turn aside from truth. ${ }^{99}$ Objective knowledge was attainable only by explicitly resisting the 'false weight' of 'familiar experiences'. ${ }^{100}$ Even though the 'intuition of inwardness, of intimacy, so strongly connected with the substantialist intuition claims to explain welldefined, scientific phenomena', the practice of scientific objectivity entails that one 'must

\footnotetext{
96 Meynert, 'Anatomie der Hirnrinde', op. cit. (note 23), 45.

${ }^{97}$ In contrast to Borck, who describes Meynert's metaphors as shuttling 'back and forth between anatomy and meaning', it is not clear what sort of proverbial gap exists between the material and metaphor in such basic images as the brain fibre. Borck, op. cit. (note 92).

${ }^{98}$ Charles Taylor suggests that the 'modern notion of interiority' derives from the cultural belief since Augustine that the soul had or was a 'unicity of locus' collected or deposited in some innermost site accessible only to God. As such, the 'opposition "inside-outside" plays an important role [in] our languages of self-understanding'. Taylor, op. cit. (note 6), 111, 119-20, 140; Goldstein, op. cit. (note 69), 6-7.

99 Bachelard, The Psychoanalysis of Fire, op. cit. (note 9), 1-5, 14-5; Gaston Bachelard, La Formation, op. cit. (note 83), 6, 13; Gaston Bachelard, The Philosophy of No: A Philosophy of the New Scientific Mind, trans. G.C. Waterston (New York: Orion Press, 1968), 13.

${ }^{100}$ Bachelard, The Psychoanalysis of Fire, op. cit. (note 9), 5.
} 
constantly denounce this claim to inner depth' ${ }^{101}$ Such denunciation and detachment corresponded on an individual level to the large-scale 'epistemic ruptures' Bachelard described in the history of science. Fundamentally, it hinged on a 'dialectic' between object and image and between science and the unconscious. ${ }^{102}$ But if the image of mental interiority is itself a derivative of history, not a universal of the mind, Meynert's work can be seen as both part of the historical project of anatomical science to elaborate the brain and an extension of the material imagination to 'catch' the mind from inside.

\section{Conclusion}

That Meynert was only partly successful in this undertaking is equally important. Towards the end of his career and especially after his death, former colleagues voiced suspicion concerning his methods and models. Some accused him of not basing his theories on empirical observations but rather 'fantastic constructions'. ${ }^{103}$ Others wondered whether his emphasis on dissection might have a harmful influence by distracting psychiatrists from their clinical duties. ${ }^{104}$ Finally, perhaps the most barbed critique was encapsulated in the smear word, 'neuromythology' [Hirnmythologie]. ${ }^{105}$ According to many, that was the essence of Meynert's professed anatomical teaching. Where he pretended to science, he tended toward myth.

Such an apparent failure of Meynert's project, however, underscores the question why his research was effective in the first place. If anything, it exposes all the more the historical contingency of his theory of brain function and its circumscribed salience. And yet, some of the basic elements of that theory, mythological or not, have of late found new credence in the forms of neurological connectionism, 'brain hodology' and 'connectomics'. ${ }^{106}$ While that potential relationship between Meynert's model of the brain and the present falls outside the scope of this paper, it remains instructive to consider how his theory could arouse such antipathy and yet command renewed respect. Part of the answer, I argue, lies in his rhetorical-anatomical imagination - specifically his material images of the brain's depth and mind's interiority.

Perhaps we cannot get away from this material language of bundles and paths. Some sort of connecting threads, weaving an 'inner' and 'outer', some image of deep roots holding together an 'upper' and 'lower': they have become part of our very concepts about

\footnotetext{
101 Ibid., 68, 73.

102 Gaston Bachelard, Water and Dreams: An Essay on the Imagination of Matter, trans. Edith Farrell, The Bachelard Translations (Dallas: Pegasus Foundation, 1983), 17; Bachelard, La terre et les rêveries du repos, op. cit. (note 8), 9. By way of some contrast, especially concerning the 'object' versus the 'thing', see Bruno Latour, 'Why Has Critique Run Out of Steam: From Matters of Fact to Matters of Concern', Critical Inquiry, 30 (Winter 2004), 236.

${ }^{103}$ Former student and co-founder of the 'neuron doctrine', Auguste Forel, quoted in Hakosalo, op. cit. (note 16), 177.

104 Engstrom, op. cit. (note 10), 123-5.

${ }^{105}$ Karl Jaspers, 'Die phänomenologische Forschungsrichtung in der Psychopathologie', Zeitschrift für die gesamte Neurologie und Psychiatrie, 9, 1 (1912), 416; Henri F. Ellenberger, The Discovery of the Unconscious (Basic Books, 1970), 284; Albrecht Hirschmüller, Freuds Begegnung mit der Psychiatrie: Von der Hirnmythologie zur Neurosenlehre (Tübingen: diskord, 1991); Engstrom, op. cit. (note 10), 123; Guenther, 'Recasting Neuropsychiatry', 210n.

106 Olaf Sporns, et al., 'The Human Connectome: A Structural Description of the Human Brain', PLoS Comput Biol, 1, 4 (30 September 2005), 245-51; Marco Catani and Marsel Mesulam, 'What Is a Disconnection Syndrome?', Cortex, Special Issue on 'Brain Hodology - Revisiting Disconnection Approaches to Disorders of Cognitive Function', 44, 8 (September 2008), 911-13; D.C. Van Essen and K. Ugurbil, 'The Future of the Human Connectome', NeuroImage, 20 Years of fMRI, 62, 2 (August 15, 2012), 1299-1310.
} 
how concepts work. ${ }^{107}$ As Meynert delineated the fibres and imagined their paths with these material images, he was said to have 'en-souled the brain', or conversely, to have 'em-brained the soul'. ${ }^{108}$ Either way, he animated the one as much as he substantiated the other, and no more by 'mere' anatomy than by 'mere' metaphor but rather through a 'material-discursive circuit' ${ }^{\text {' }}$ ' belonging at once to science and the imagination.

${ }^{107}$ Lakoff and Reddy each discuss the metaphors of travel and transmission, containment and captivity, in relation to theories of cognition. In contrast, Cussins suggests a 'non-conceptual constructionist' theory of mind that he calls 'cognitive trails'. George Lakoff, 'The contemporary theory of metaphor', in Andrew Ortony (ed.), Metaphor and Thought, 2nd edn (Cambridge: Cambridge University Press, 1993), 212, 214, 219-20; Michael Reddy, 'The conduit metaphor', in Andrew Ortony (ed.), Metaphor and Thought (Cambridge: Cambridge University Press, 1979), 287-8, 295; Adrian Cussins, 'Content, Embodiment and Objectivity: The Theory of Cognitive Trails', Mind, 1992, 651-88.

108 Gabriel Anton, 'Theodor Meynert', Deutsche Irrenärzte: Einzelbilder ihres Lebens und Wirkens, Vol. 2 (1924), 126; Kiefer, op. cit. (note 6), 36.

109 Rheinberger, op. cit. (note 41), 316. 